\title{
Computer Network Connection for the Advanced Test Reactor Critical (ATR-C) Facility
}

Idaho National Laboratory

August 2016

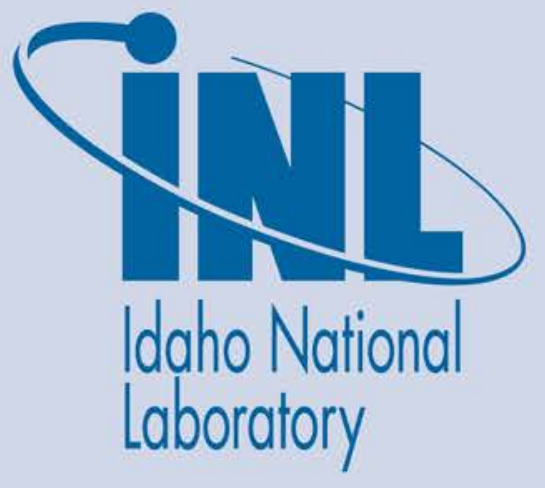

The INL is a U.S. Department of Energy National Laboratory operated by Battelle Energy Alliance 
INL/EXT-16-39504

\section{Computer Network Connection for the Advanced Test Reactor Critical (ATR-C) Facility}

Idaho National Laboratory

August 2016

Idaho National Laboratory
Idaho Falls, Idaho 83415

http://www.inl.gov

Prepared for the

U.S. Department of Energy

Assistant Secretary for __, OR Office of

Under DOE Idaho Operations Office

Contract DE-AC07-05ID14517 


\section{DOE-ID NEPA CX DETERMINATION Idaho National Laboratory}

CX Posting No.: DOE-ID-INL-16-088

SECTION A. Project Title: Computer Network Connection for the Advanced Test Reactor Critical (ATR-C) Facility

SECTION B. Project Description and Purpose:

The proposed activity would install a computer network connection in the Advanced Test Reactor Critical (ATR-C) Facility by running conduit from the west side office area near the entry into ATR-C and pulling in four category 5E (Cat5E) cables. The proposed activity would include running the Cat5E cables and associated conduit approximately $70 \mathrm{ft}$ through the corridor from the office area and through the block wall into the southwest corner of ATR-C.

SECTION C. Environmental Aspects or Potential Sources of Impact:

\section{Air Emissions}

Project activities have the potential to generate fugitive dust.

\section{Disturbing Cultural or Biological Resources}

Test Reactor Area (TRA)-670 is eligible for nomination to the National Register of Historic Places and is considered a Category 1 historic property. Removal and/or changes of original features may adversely impact this historic property; however, the project activities as described are exempt and may proceed as described without further cultural resource review. The described project activities fall under exemption 2 (routine maintenance activities) listed in Table 2 (Idaho National Laboratory Cultural Resource Management Office. Idaho National Laboratory Cultural Resource Management Plan. DOE/ID10997, revision 6, Idaho Falls, Idaho: U.S. Department of Energy, Idaho Operations Office, 2016, pg 51).

\section{Generating and Managing Waste}

Project activities may generate a variety of waste. It is anticipated that the following types of waste could be generated:

- Industrial (non-hazardous, non-radioactive) waste includes wastes such as boxes, wood, wiring, paper, insulation, and some metals.

- Hazardous wastes have the potential to be generated during project activities involving systems or equipment containing hazardous chemicals, or by using hazardous chemicals to clean or decontaminate equipment and systems. Hazardous metal waste (e.g., lead, electronics, brass, metal containing paints, etc.) may also be generated.

- $\quad$ Polychlorinated Biphenyl (PCB) waste could be generated when performing maintenance associated with pre-1982 equipment/materials such as capacitors, lubricants/dielectric fluids, transformers/bushings, painted surfaces and other electrical equipment/components.

\section{Releasing Contaminants}

Typical construction chemicals such as lubricants, paints, adhesives, etc., will be used during the project. Although not anticipated, chemical use has a potential for spills.

\section{Using, Reusing, and Conserving Natural Resources}

All materials would be reused and/or recycled where economically practicable. All applicable waste would be diverted from disposal in the landfill where conditions allow. The project would practice sustainable acquisition.

SECTION D. Determine Recommended Level of Environmental Review, Identify Reference(s), and State Justification: Identify the applicable specific categorical exclusion from 10 Code of Federal Regulation (CFR) 1021, Appendix B, give the appropriate justification, and the approval date.

For Categorical Exclusions (CXs), the proposed action must not: (1) threaten a violation of applicable statutory, regulatory, or permit requirements for environmental, safety, and health, or similar requirements of Department of Energy (DOE) or Executive Orders; (2) require siting and construction or major expansion of waste storage, disposal, recovery, or treatment or facilities; (3) disturb hazardous substances, pollutants, contaminants, or Comprehensive Environmental Response, Compensation, and Liability Act (CERCLA)excluded petroleum and natural gas products that pre-exist in the environment such that there would be uncontrolled or unpermitted releases; (4) have the potential to cause significant impacts on environmentally sensitive resources (see 10 CFR 1021). In addition, no extraordinary circumstances related to the proposal exist that would affect the significance of the action. In addition, the action is not "connected" to other action actions (40 CFR 1508.25(a)(1) and is not related to other actions with individually insignificant but cumulatively significant impacts (40 CFR 1608.27(b)(7)).

References: National Environmental Policy Act (NEPA) Implementing Procedures, Final Rule, 10 CFR 1021, Appendix B to Subpart D, Categorical Exclusion B1.7 "Electronic equipment" 


\section{DOE-ID NEPA CX DETERMINATION \\ Idaho National Laboratory}

CX Posting No.: DOE-ID-INL-16-088

Justification: The proposed activities are consistent with CX B1.7 "Acquisition, installation, operation, modification, and removal of electricity transmission control and monitoring devices for grid demand and response, communication systems, data processing equipment, and similar electronic equipment."

Is the project funded by the American Recovery and Reinvestment Act of 2009 (Recovery Act) $\quad \square$ Yes $\quad \square$ No

Approved by Jason Sturm, DOE-ID NEPA Compliance Officer on: 7/27/2016 